\title{
Pembuatan Aplikasi Front Desk Agent Duty Berbasis Web Pada PT. MANE Indonesia
}

\author{
Ferlyana Endramadhanti Rizal \\ Ronny Juwono ${ }^{2}$ \\ President University \\ Bekasi, Indonesia \\ ${ }^{1}$ ferlyanaer@gmail.com \\ ${ }^{2}$ ronny@president.ac.id
}

\begin{abstract}
Abstrak - Aktivitas sebagai front desk agent duty merupakan salah satu hal penting dalam setiap perusahaan. Dalam aktivitas sebagai front desk PT. MANE Indonesia, untuk melakukan permintaan stationary dan voucher taxi melalui email lalu input manual di microsoft excel. Hal tersebut sangat mengulur waktu seorang front desk agent dalam penginputan dan pembuatan laporannya. Sebuah sistem informasi dapat memberikan data yang akurat dan berguna untuk mencapai tujuan tertentu. Misalkan membuat keputusan berapa banyak kebutuhan stationary suatu perusahaan untuk bulan selanjutnya, dan masih banyak lagi hal-hal yang butuh di dokumentasikan dengan baik. Maka diciptakan aplikasi FDAD PT. MANE Indonesia. Dalam hal tersebut, diperlukan data valid yang didokumentasi serta terintegrasi. Aplikasi yang dibuat ini untuk mengurai kekurangan tersebut.
\end{abstract}

\section{PENDAHULUAN}

Penerapan teknologi informasi banyak digunakan perusahaan guna mengurai masalah efisiensi waktu, tenaga dan biaya. Penerapan teknologi informasi menyebabkan perubahan pada kebiasaan kerja.

Setiap perusahaan memiliki staff yang bertanggung jawab sebagai Front Desk Agent (FDA) atau dengan kata lain Resepsionis. Di PT. MANE Indonesia, FDA bertanggung jawab mengelola data buku tamu dan mengelola data inventory stationary dan voucher taxi. Saat ini semua pekerjaan tersebut dikelola secara manual. Tamu yang berkunjung mengisi lembaran form kunjungan, data inventory stationary dan voucher taxi dicatat ke buku besar dan tidak dapat diketahui oleh departemen lain jika membutuhkan barang tersebut, keluar masuknya barang dari inventory stationary dan voucher taxi harus dicatatkan secara manual ke buku besar setiap hari dan sekali sebulan untuk pencatatan keseluruhan dengan
Microsoft Excel. Hal ini tentu sangat mengulur waktu dan tidak efektif untuk dilakukan seorang FDA.

Untuk memudahkan PT. MANE Indonesia, maka diperlukan sebuah sistem dimana data tamu/mitra perusahaan yang datang dan data inventory kantor terkendali dengan menggunakan aplikasi yang akan dibuat.

\section{TEORI}

Pada bagian ini akan dipaparkan teori yang mendukung langkah-langkah yang digunakan dalam pembuatan aplikasi front desk agent duty ini.

Database berbeda dengan Database Management System (DBMS). DBMS adalah kumpulan program yang digunakan untuk mendefinisikan, mengatur, dan memproses database.

Pengelolaan database dengan MySQL harus dilakukan dengan mengetikkan baris-baris perintah yang sesuai (command line) untuk setiap maksud tertentu. PHP My Admin dapat membuat tabel, mengisi data dan lain-lain dengan mudah tanpa harus hafal perintahnya.

\section{METODOLOGI}

Rapid Aplication Development (RAD) adalah salah satu metode pengembangan suatu sistem informasi dengan waktuyang relative singkat. Untuk pengembangan suatu sistem informasi yang normal membutuhkan 180 hari, akan tetapi dengan menggunakan metode RAD suatu sistem dapat diselesaikan hanya dalam waktu 30-90 hari [13]. 


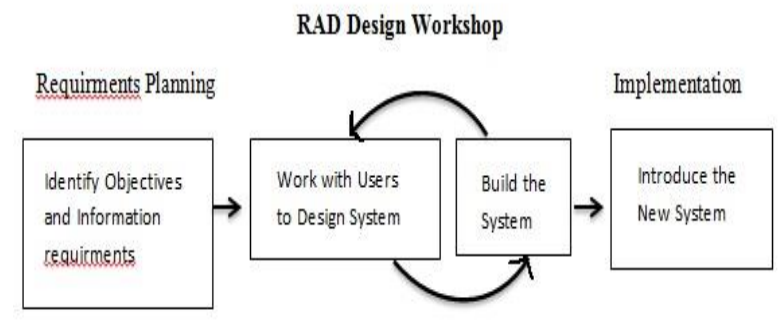

Gambar 1 Tahapan RAD [13]

Proses ini membuat kerangka kerja arsitektur data untuk kebutuhan informasi atau fungsi bisnis. PT. MANE Indonesia diklasifikasikan sebagai obyek penelitian. Arsitektur data tersebut melingkupi nama perusahaan, alamat perusahaan, data tamu, data permintaan dinamakan sebagai entitas. Setelah data tersebut terkumpul, dilakukan perencanaan arsitektur untuk sistem aplikasi. Setelah rancangan sistem, dilakukan pembuatan infrastruktur teknologi, yaitu meliputi hardware dan software yang digunakan untuk mendukung sistem yang akan dibuat.

\section{2) Design Workshop}

Membuat aliran informasi berikut perubahannya mulai dari proses masukan (input) dan keluaran (output) menggunakan permodelan berorientasi objek yaitu Unified Modeling Language (UML). Pada tahap ini membuat Use Case Diagram, Activity Diagram.

\section{3) Coding}

Dari data yang ada pada tahap sebelumnya, diterjemahkan ke dalam bentuk Bahasa pemrograman. Bentuk aplikasinya adalah website, data server menggunakan MySQL, server side programming language menggunakan PHP dan untuk meningkatkan tampilan web, validasi form, membuat cookie menggunakan javascript.

4) Tahapan Keseluruhan Deangan berdasarkan pada tahapan-tahapan tersebut diatas makan proses utama pengembangan suatu sistem dengan menggunakan metode RAD adalah sebagai berikut :

- Pengembang membuat prototype berdasarkan kebutuhan-kebutuhan yang sudah didefinisikan sebelumnya.

- Desainer melakukan penilaian terhadap prototype.

- User melakukan uji coba pada prototype dan memberikan masukan mengenai kebutuhankebutuhan yang kurang.

- User dan developer melakukan pertemuan untuk memberikan penilaian terhadap produk secara bersama-sama, menyesuaikan kebutuhan serta memberikan komentar apabila diperlukan perubahan.

\section{GAMBARAN PIRANTI LUNAK}

Aplikasi FDAD PT MANE Indonesia ini adalah suatu aplikasi yang digunakan untuk membantu seorang Front Desk Agent Duty atau Receptionist untuk mempermudah rekap data tamu, mengendalikan stok stationary dan voucher taxi yang dibutuhkan oleh karyawan setiap department. Aplikasi ini dibuat dengan menggunakan bahasa pemrograman PHP, sedangkan untuk databasenya menggunakan mysql. Aktor dalam aplikasi ini di bagi menjadi admin, user receptionist dan user karyawan setiap department. Kerja sistem aplikasi yang dibangun ditunjukkan pada gambar 2.

Di dalam aplikasi ini untuk aktor admin diasumsikan hanya satu orang saja yang mengelola dan bertanggung jawab atas data-data yang dimasukkan. Admin memliki hak akses untuk mengelola data informasi yang ingin ditampilkan seperti data tamu, data barang, data voucher taxi, cetak report dan kelola akun. Sedangkan untuk aktor receptionist memiliki hak akses untuk menginput data tamu, barang, voucher taxi, approval pengambilan barang dan voucher taxi, dan cetak report. Serta actor karyawan memiliki hak akses untuk meminta / request barang dan voucher taxi ke receptionist. Dan semua dapat diakses melalui komputer yang tertanam aplikasi ini. 


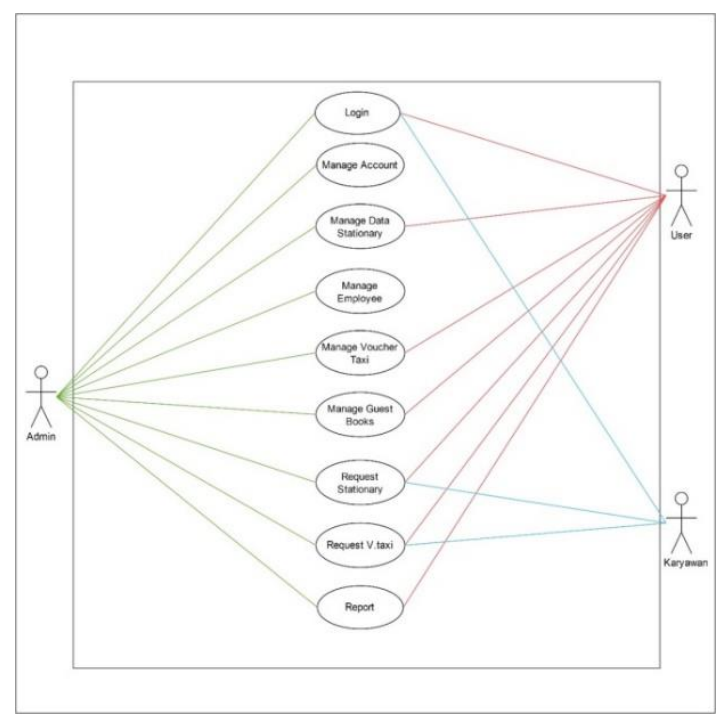

Gambar 2. Use Case Diagram

\section{HASIL DAN PEMBAHASAN}

Bagian ini akan menjelaskan hasil dari tahapan maupun tampilan yang ada di aplikasi.

Salah satu tampilan yang akan dibahas disini adalah admin dapat melakukan pengeditan maupun penghapusan data. Berikut gambar tampilan data barang sebabagaimana diperlihatkan pada gambar 3 .

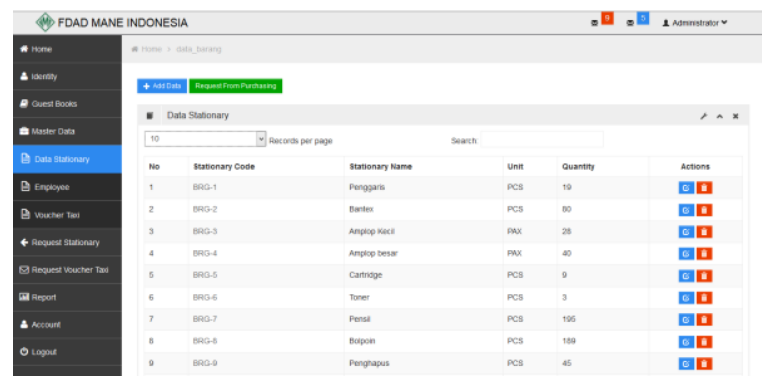

Gambar 3. Tampilan Data Barang

Berikut adalah source code yang digunakan untuk menjalankan fungsi pada tampilan aplikasi seperti diperlihatkan gambar 4, 5, dan 6

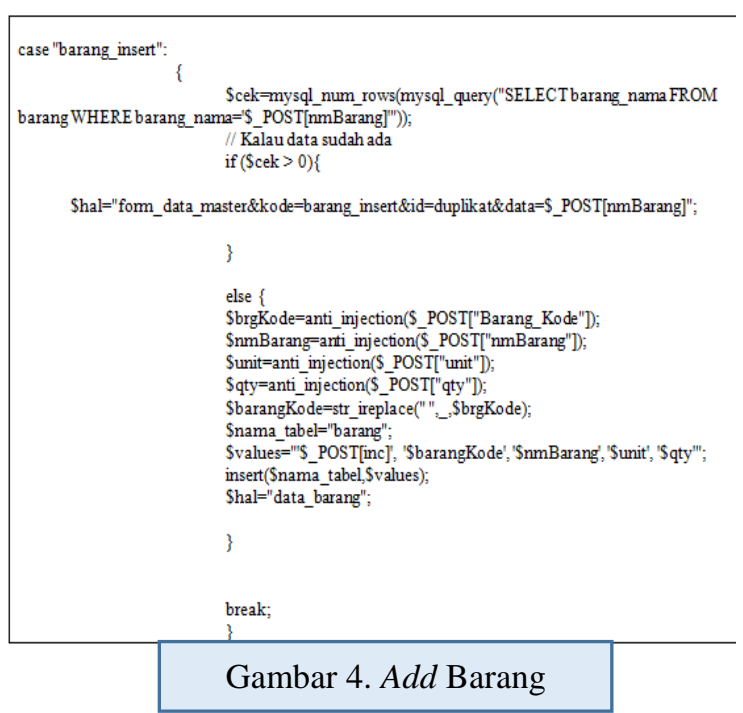

Tampilan diatas merupakan hasil report voucher taxi yang sudah dipesan / diinput oleh karyawan seperti ditunjukkan gambar 7 .

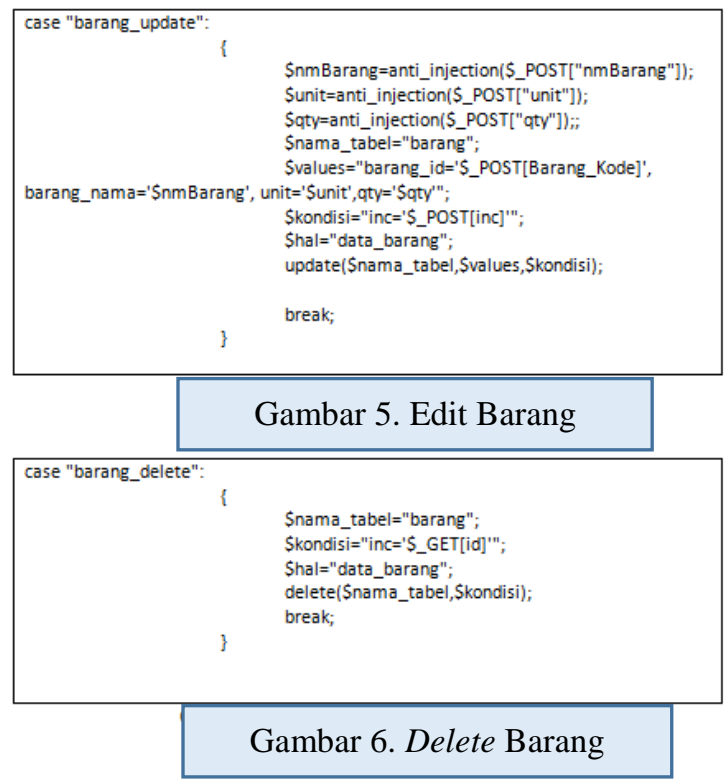

Selain melakukan penginputan data, aplikasi ini juga memiliki hasil akhir yaitu lembar laporan / report. 


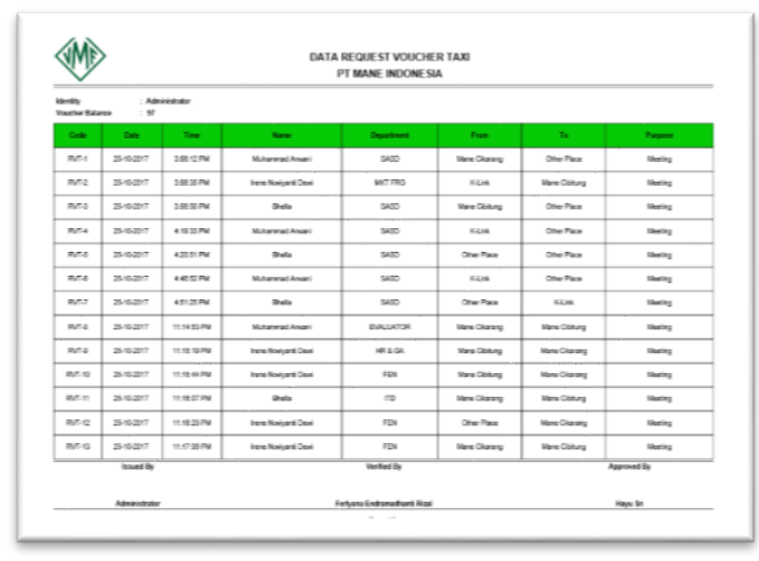

Gambar 7. Tampilan Report

\section{KESIMPULAN}

Berdasarkan hasil pengumpulan, pengolahan, analisis data dan perancangan aplikasi, maka dapat diambil kesimpulan bahwa aplikasi FDAD PT. MANE Indonesia berbasis web ini dapat mempermudah user dalam mengumpulkan laporan / report dan memudahkan karyawan dalam melakukan request stationary dan voucher taxi. Dengan adanya sistem ini memberikan transparansi antara perusahaan dengan karyawan tiap department karena bukti request tertampil di sistem.

\section{DAFTAR PUSTAKA}

[1] Denis, A. et al. System Analysis and Design With UML Version 2.0: An ObjectOriented Approach Ed. 4. USA: John Wiley \& Sons, Inc. 2012.

[2] Herdiansyah, H. Metodologi Penelitian Kualitatif; Untuk Ilmu-Ilmu Sosial Ed. 3. Jakarta: Salemba Humanika. 2014.

[3] HM, Jogiyanto. Analisis \& Desain Sistem Informasi : Pendekatan Terstruktur Teori dan Praktek Aplikasi Bisnis. Yogyakarta : Andi. 2010.
Indrajani. Perancangan Basis Data dalam All in 1. Jakarta: PT Elex Media Komputindo. 2015

J.B. de Carvalho, R.Bartholo, F.Duarte . Hospitality Experience :Creating Value by The Front-Desk Work Analysis and organizational innovation. Brazil: Elsevier Espana, S.L.U. 2016.

Pressman, R.S, Ph.D. Software Engineering; A Practitioner's Approach Ed. 7. New York: McGraw-Hill. 2010.

Pressman, R.S, Ph.D. Rekayasa Perangkat Lunak: Pendekatan Praktisi Edisi 7. Ed. 1. Terjemahan: Adi Nugroho, et al. Yogyakarta: ANDI. 2012.

Pusat Bahasa Departemen Pendidikan Nasional. Kamus Besar Bahasa Indonesia Ed. 4. Jakarta: Gramedia Pustaka Utama. 2008.

Raharjo, B. "Belajar Otodidak MySQL”

Bandung: Informatika Bandung, 2015

Romney, M.B. dan Steinbart, P.J. Sistem Informasi Akuntansi Edisi 13. Ed. 4. Terjemahan: Kikin Sakinah Nur Safira dan Novita Puspasari. Jakarta: Salemba Empat. 2015.

Rosa, A.S. dan Shalahuddin, M. Rekayasa Perangkat Lunak Terstruktur dan Berorientasi Objek Ed. 4. Bandung: Informatika Bandung. 2016.

Sommerville, I. Software Engineering Ed. 9. USA: Pearson Education, Inc. 2011

Agustinus, Noertjahyana, 2002. Jurnal Informatika, Vol. 3, No. 2 : 74-79. 